\title{
DO COMMUNITY CULTURES AND TRADITIONS INFLUENCE ON NATURE CONSERVATION PERSPECTIVES? A CASE OF KHAO YAI NATIONAL PARK IN THAILAND
}

\author{
TEH KATE YNG $^{1 *}$ AND RITTIRONG KAOTEERA ${ }^{2}$
}

${ }^{1}$ Faculty of Communication and Creative Industries, Tunku Abdul Rahman University College, Penang Branch Campus, Pulau Pinang, Malaysia. ${ }^{2}$ Faculty of Humanities and Social Sciences, Kamphaeng Phet Rajabhat University, Kamphaeng Phet, Thailand.

*Corresponding author: tehky@tarc.edu.my

Submitted final draft: 28 December 2020 Accepted: 26 January $2021 \quad$ http://doi.org/10.46754/jssm.2021.08.020

\begin{abstract}
Numerous studies have shown that the degree of local participation and support are important to achieve conservation goals. This study seeks to explore the community cultures and traditions and its influences on their support for nature conservation activities surrounding Khao Yai National Park, Thailand. In-depth interviews were conducted face-to-face and non-participant observations were applied concurrently to confirm the reliability and validity of data from the interviews.

The findings concluded that local cultural and traditional practices area vital factor that influences perspectives of local communities on nature conservation.

First, the results revealed a strong culture of belonging to the national park among the local people where the park was regarded as home and shelter for them. The younger generations were willing to return home for jobs, and thus led to greater family intimacy.

Secondly, the respondents perceived safeguarding the national park as one of their ancestral traditional practices which has been handed down through generations.

Lastly, local rituals and beliefs about traditional spiritual values of forest also mould their positive attitudes towards conservation of culture and nature. This paper concludes that understanding the community cultures and traditions contributes to greater understanding of their perspectives which could help to enhance long-term sustainability of the national park.
\end{abstract}

Keywords: Cultures, traditions, nature conservation, perspectives, sustainability.

\section{Introduction}

In the context of addressing the environmental issues and concerns, national concerted initiatives on nature conservation have been taken by the governments of many countries to protect natural resources and their living habitats. In most developing countries including Thailand, national parks are the cornerstone of biological conservation. Although they have been set aside from human exploitation under the traditional conservation movement (Jeanrenaud, 2002; Adams, 2007; Bennett \& Dearden, 2014), it is now increasingly recognised that protected areas should place more emphasis on the human dimension of biodiversity conservation (Muhumuza \& Balkwill, 2013; Berbés-Blázquez, 2017; Vimal et al., 2018).
Many national parks are under increasing human threat and are expected not only to conserve wildlife, but also to achieve various social and economic objectives (Watson et al., 2014). This is due to the park-people conflicts resulting from the separation of natural resources and human influence have led to a growing attention from the stakeholders since the parks should play a role in sustaining local communities.

Previous research works have argued that people living in and around the national parks often impact the ability of the parks to achieve long-term conservation and sustainability objectives (Thaworn et al., 2010; Triguero-Mas et al., 2010; Jenks et al., 2013; Mamo, 2015; Mutanga et al., 2017). 
The perspectives or attitudes of local residents as well as the interactions, level of participation, and conflicts between people and national parks have become a concern of nature conservation activities effectiveness especially in developing countries.

Such an argument is based on the reality that community participation is the most powerful tool for environmental conservation in protected areas (Zhang et al., 2020). With criticism on every angle of the conservation debates, therefore, it is critical to have a better understanding that associates the perspectives of local people with environmental conservation.

Despite substantial efforts made to study the local perspectives and the contributing factors across countries, little work was focused to examine the cultural and traditional practices of local people. The argument of previous study by Brown and Verschuuren (2018) is that there is an interrelationship between people and their environments or natures will be further explored in our research.

The previous researchers affirm the cultural and spiritual significance that 'nature' holds for local people in protected and conserved areas. It remains to be demonstrated to what extent the inclusion of local people and their cultural practices in nature conservation is practised in an oldest national park, especially in the Asian countries such as Thailand.

Thereby, this paper thus contributes to assess perspectives of local communities on nature conservation activities adjacent to Khao Yai National Park. It also seeks to fill in the gaps of the existing literature by examining whether local perceptions are associated with their community cultural and traditional practices.

We develop a conceptual framework linking:

(i) people's satisfactions and perceptions, and

(ii) perceptions and human behaviour.

The conceptual framework borrows from the theories and literature on the social exchange theory (Homans, 1961; Blau, 1964) and perspective-taking paradigm in communication (Krauss \& Fussell, 1996).

Theoretically, the importance of the social exchange theory rests on the concepts of equality and reciprocity. Chibucos et al. (2005) form an argument that perceptions of equality imply the presence of reciprocity. They argue that social life requires a degree of reciprocity, meaning that, for individuals who perceive relatively balance levels of reciprocity in a social exchange process, they are more likely to feel satisfied with and yet maintain a harmonious relationship. Pham (2012) also states that the trade-off between benefits and costs is explained through the theory, which suggests that individuals will engage in and support an activity if the perceived benefits are greater than the perceived costs.

Despite previous studies on local perspectives and attitudes that have identified numerous factors as significant predictors, there are still lack of theories to explain the relationships between people's attitudes and factors. Therefore, by using social exchange theory, many quantitative and qualitative researchers have started to look at the factors likely to influence the perceived impacts of certain activities or programmes and subsequent support for their development.

In relation to the field of nature conservation, the appropriateness of social exchange theory as a theoretical framework for understanding the factors influencing local communities' perceptions was verified (Garekae et al., 2006; Ntuli et al., 2019). It can be concluded that the positive and negative impacts from national park foundation, experienced by the surrounding communities could influence their perspectives and support towards conservation.

Meanwhile, perspective-taking paradigm in communication debates on different people is assumed to have different ideas and perceptions (Krauss \& Morsella, 2000). This interpretation is supported by Adler (1991) who comments that the greater of difference in background 
and the greater the difference in meanings were attached to particular words and behaviours. This is because translating meanings into words and behaviours is based upon a person's cultural background and is different between one person to another. Based on these different strands of literature and theories, we argue that receiving benefits from the national park has a positive impact on people's perceptions of conservation, while the way people perceive conservation is based on their experiences, backgrounds and knowledge. This in turn affects their behaviours and final conservation attempts whether support or not for the national park.

\section{Literature Review}

There is tremendous amount of literature that enhances our understanding of local communities' perspectives on nature conservation. A number of recent studies have generally found that benefits from conservation such as socio-economic benefits from the protected areas have increased positive effects on local attitudes (Jaafar et al., 2013; Clements et al., 2014; Bragagnolo et al., 2016; Harun et al., 2018; Abukari \& Mwalyosi, 2020), whilst costs associated with conservation such as wildlife damaging crops (Timsina, 2014; Massé, 2016), restriction of access to traditionally used forest resources (Nana \& Tchamadeu, 2014; Thondhlana \& Cundill, 2017; Munanura et al., 2018), conservation-induced displacement (Kabra, 2009; Shahabuddin \& Bhamidipati, 2014) and misconceptions about the park management (Guzman et al., 2020) may resulted in negative effects.

Besides, many researchers are increasingly aware of the impact of religion and culture as important sources of morals and values for many people that influence their views and attitudes towards environmental issues (Hope \& Jones 2014; Sachdeva, 2016; Murray \& Agyare, 2018). Park (2005) affirms that, a person's personality or attitude has been sometimes described as the individual and subjective aspect of culture. According to Anderson and Gale (1992), culture is seen as "a dynamic mix of symbols, beliefs, languages and practices that people create, but not a fixed thing or entity governing humans" (p. 3). The concept of cultural traditions in anthropology has historically denoted a broad body of beliefs, customary behaviours and modes of social organisation that are transmitted over generations (Head et al., 2005).

A relevant previous research conducted in China records that the sacred natural sites play an important cultural role and offers religious meaning for the rural communities around the region of northwest Yunnan (Allendorf, Brandt, \& Yang, 2014). Their study indicates local people's appreciation towards the existence of forests close to their villages and they primarily view the sacred forests as religious sites. Another recent research carried out in Muna Island in Southeast Sulawesi, Indonesia, showed that in preserving forests Munanese people uphold the tradition of taboo which they consider important in controlling how people morally behave, as well as guiding human behaviour towards their natural environment. Trees and forests

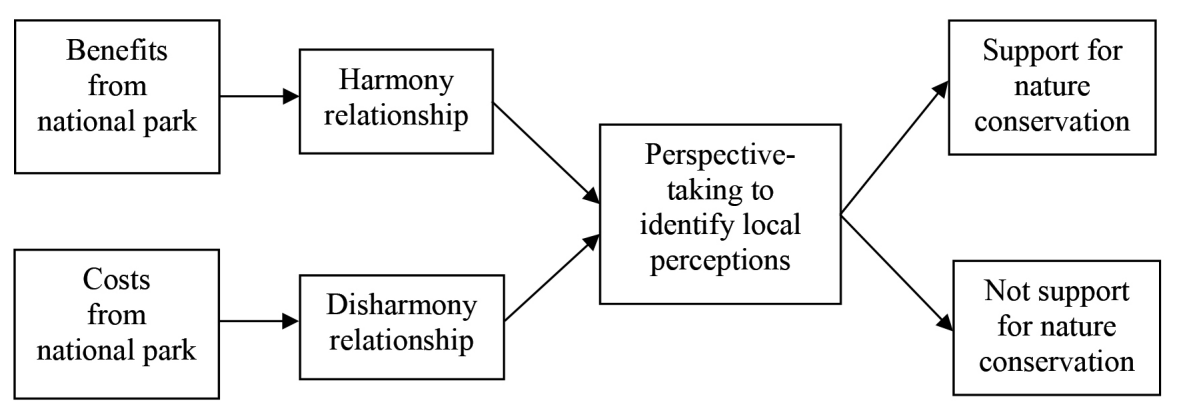

Figure 1: Conceptual framework employed in this study 
are believed to have potentials for developing resources and maintaining ecosystems, hence they should be sacred and utilised as needed (Taena et al., 2016).

The relationship between religion and morality has long been hotly debated (McKay \& Whitehouse, 2015). For most cultures, religion is a primary means of defining right and wrong. Buddhism, for instance, with a total of about 300 million practitioners found in many Asian countries, commits to the ideal of nonviolence. It teaches that right actions lead to progress towards nirvana while negative actions, such as killing animals, leads to regression from that goal (Negi, 2005). In Thailand, the local culture is deeply influenced by religion with nearly 94 per cent of the countries population practicing Buddhism. Often referred to as "The Land of Buddhism", Thailand's constitution specifies that their King must be a Buddhist and the Guardian of Buddhism. Hence, to the Thai people as a whole, Buddhism strengthens their culture and philosophy with specific control on the art and literature, ethics and morality where significance sight can be seen from the majority of their folkways and festivals (Kusalasaya, 2005).

In addition, the translation of the word "nature" in Thai is "thamachat". This word which originates in Buddhism brings meaning "things that occur according to forces of the universe such as human beings, animals, trees, etc." (Laungaramsri, 2001). Therefore, thamachat means an ideal that humans are a part of nature. In other words, the meaning of nature in the Thai language has been hypothesised to support the new conservation approach to integrate the role of nature conservation, social and cultural development processes which have been discussed earlier. It is suggested that humans, earth, and land are integrally connected to each other; therefore, the utilisation of natural resources must comply with cultural and ecological required of local society.

\section{Methods}

\section{Study Site}

Khao Yai National Park was established in 1962. Being a national symbol of nature conservation, the park was designated as an ASEAN Heritage Park in 1984. In 2005, together with three other parks in the same range of the Dong Phayayen Mountains, Khao Yai National Park was proclaimed as the United Nations Educational, Scientific and Cultural Organisation (UNESCO) World Heritage Site under the name "Dong Phayayen - Khao Yai Forest Complex" (United Nations Educational, Scientific and Cultural Organisation, 2013). As the third largest national park in Thailand, blessed with rich biodiversity such as the lush and mountainous landscape as well as the pounding waterfalls and creeks, the Khao Yai National Park is named after the large mountain range that divides central Thailand from north-eastern Thailand. It covers four provinces: Nakhon Nayok, Prachin Buri, Nakhon Ratchasima and Saraburi.

The park encompasses a mountainous area of 2,168 square kilometres which comprises dry deciduous and evergreen forest, tropical moist evergreen forests, hill evergreen forests, and grasslands. The forest provides a wide range of ecosystems and habitats for at least 2,000 species of plants, over 300 species of bird, 70 species of mammals, and 74 species of reptiles and amphibians (Myers, 2016). It is a major tourist attraction of Thailand because of its beautiful scenery, rich forest, waterfalls, abundant wildlife and close to Bangkok, the capital city of Thailand (Suwanwaree \& Aroon, 2014).

However, due to its rich biodiversity, Khao Yai is also a magnet for illegal collecting, logging, and poaching. For example, Siamese Rosewood (Dalbergia cochinchinensis) is listed as "vulnerable" on the IUCN Red List of Threatened Species. Situated close to the ThaiCambodian border, the Dong Phayayen - Khao Yai Forest Complex is particularly susceptible to poaching networks from Cambodia, with the collaboration of both Thai and Cambodian 
nationals. Not only illegal harvesting of highvalue timber species, but the poachers also hunt and kill other species of wildlife which have seriously impacted the forest ecosystem (Cadena, 2014).

In addition, the Forestry Faculty of Kasetsart University in Thailand has also concluded that Khao Yai is subject to continuous human disturbance for several reasons including conversion of forest land to agricultural land in areas adjacent to the park, limited income causes the villagers to harvest and sell forest resources, local villagers both inside and outside of the park lack knowledge and goodwill needed to support conservation (Panusittikorn \& Prato, 2001). Hence, nature conservation initiatives are increasingly important surrounding this national park and this is the main reason of selecting Khao Yai as a study site for this research. Moreover, as continued destruction of wildlife habitat has occurred due to local involvement in illegal logging and poaching in the park, the researchers wish to assess the perspectives of local communities on conservation efforts at Khao Yai National Park to identify accurate conservation strategies.

\section{Data Collection}

Our research methodology consists of in-depth interviews and non-participant observations with residents of villages surrounding Khao Yai. The strength of the qualitative methods used in this research lies in the depth of the understanding of the points of view of different people, and the social and cultural contexts within which they live (Myers, 2013). In comparison to quantitative method, the qualitative approach often expands upon what has been found in surveys and attempts to explain why the audience or public thought or behaved as it did (Heath, 2013).

Certain criteria for selecting the target villages in Khao Yai were set in order to identify research population and to ensure a proportional representative of their local communities, including:

(i) the villages should be located in and near to the conservation area which is not more than five kilometres from the Khao Yai National Park;

(ii) the socio-economic activities of local people must depend on ecotourism development

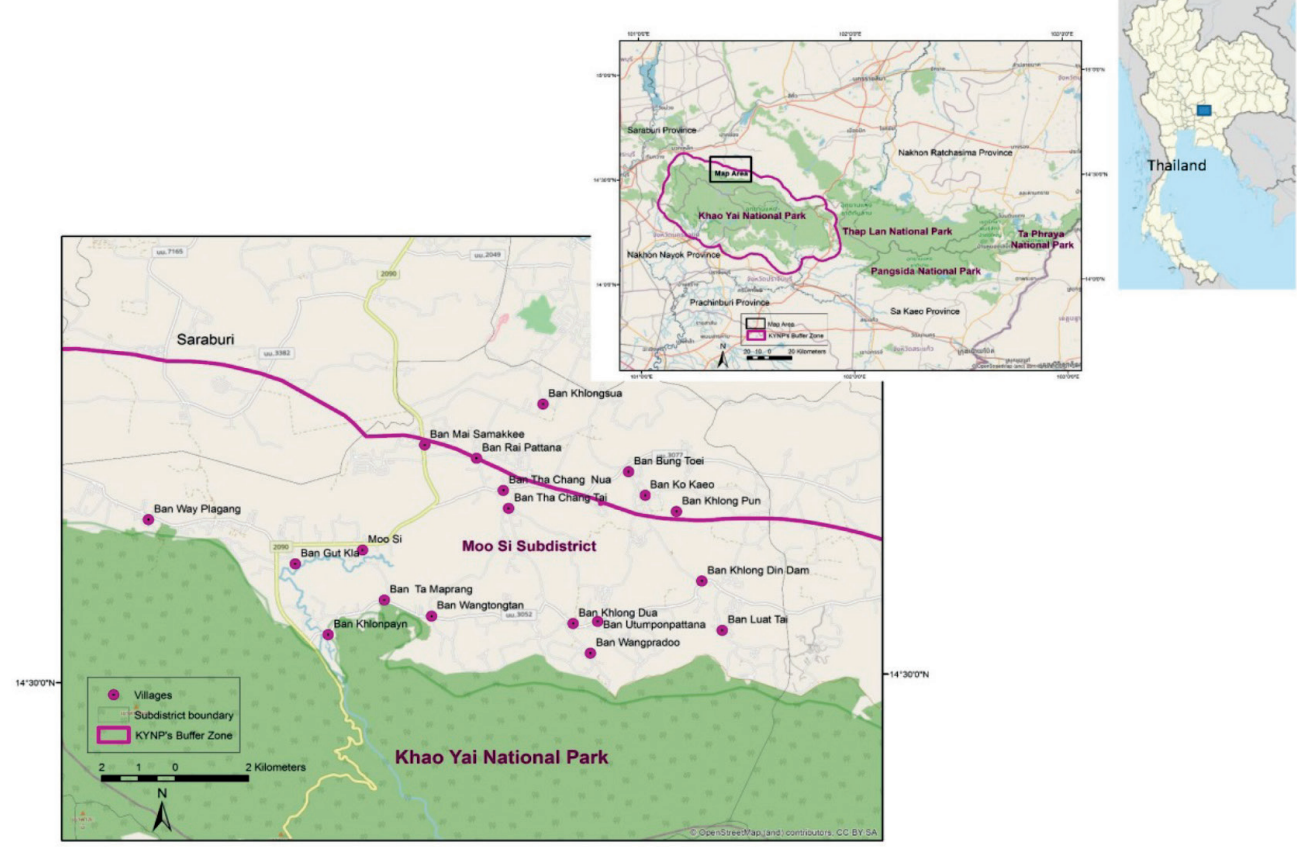

Figure 2: Map of Khao Yai National Park with communities (Cartography by OpenStreetMap contributors). 
either employed or involved in tourism business such as park rangers, park guards, tourist guides, boat drivers, chalet and food service operators;

(iii) the respondents selected should be willing to provide information voluntarily, and

(iv) the personal safety of the researcher during the fieldwork must clearly be protected. Based on these criteria, a total of nine Moo (village in Thai) were selected as target population for this study: Moo 3, Moo 4, Moo 5, Moo 6, Мoo 10, Moo 11, Мoo 13, Moo 17, and Moo 18.

With the help of the village chiefs, purposive sampling was then applied to sample out a total of 15 interview respondents among those who have been living in the study area for more than ten years. They have their traditional ways of life that could not be separated from the national parks. Their local knowledge and experience around the study areas would generate particularly useful information for this study. They were also selected from different occupational backgrounds comprising village chief, elder, retired civil servant, teacher, farmer, resort, and restaurant operators, as well as nature guides. People with various responsibilities and knowledge backgrounds would also reveal different perspectives and understanding towards conservation attempts.

We conducted semi-structured interviews which covered a list of questions including:

(1) Do you think the national parks are important? Why?

(2) What are the roles of national parks?

(3) How do national parks affect your daily life?

(4) What are the implications of national parks establishment on the local cultures and traditions?

(5) How do local cultures and traditions affect your perspective on nature conservation?

Each of the questions asked during the interviews was adapted from Labov's (1982) evaluation model of narrative. The importance of the narrative model is to lead the respondents to tell their views and experience in the form of a story.

We also conducted non-participant and unstructured observations in the households and communities. We were not directly involved in the situation to become part of their community but rather observed and recorded the respondents' behaviours. We only looked from outside and there was no direct interaction with the respondents (Sampieri et al., 2006). We observed the respondents' actions and behaviours, the physical and social environment of the village areas, ways of living and traditional practices of the local people, as well as other daily activities related to natural resources. Observation is important in giving the study higher accuracy and reliability by confirming the information obtained from interviews. It helps to clarify certain issues that could not be gathered by the interview approach alone. This is because some interviewees would not be able to explain issues clearly, or sometimes they may show items or places to express what they wanted to talk.

\section{Data Analysis}

A narrative analysis method was then used to analyse the interview transcripts. This analysis method has been widely used by researchers as being of fundamental importance to learn, examine and analyse the perspective of participants in order to understand their culture and experiences in real life (Richmond, 2002), which is the aim of this study. Qualitative data collected from the interviews were analysed according to the structural analysis of narrative derived from Labov (1982) in order to investigate the ways of participants' experience through their stories telling. We explored and arranged the stories told by the interviewees into basic structures that includes abstract, orientation, complicating action, evaluation, result and coda. Meanwhile, to analyse the observation data, we used a "double-entry notebook" suggested by Driscoll (2011). In this type of observation log, two columns were made to clearly separate: 
1) the details and facts that were observable such as the scene, behaviours and actions of the respondents, and

2) the assumptions and interpretations about the facts. However, the judgements and overall conclusion about the facts or events were made based on the researchers' own feelings.

\section{Results}

\section{A Culture of Belonging}

When answering to our question, "Do you think national parks are important? Why?", the respondents presented strong views about the protection of natural resources in the park as a key component of national heritage protection. Expressing of her appreciation to the national park establishment, the owner of a fruit orchard remarked.

As a villager in Khao Yai, I am really proud and grateful to be a native here because I can protect the national treasure that we have today, and I continue this culture to the next generation.

The interviewees expressed their favourable perceptions on Khao Yai National Park and when they were asked about the reasons, few of them emphasised their cultural bonds with nature. The park is important to fulfil their sense of belonging as their home and recall their childhood memories and experiences. A female villager has regarded the national park as her "home". With regard to her feelings about this conservation site, she felt a unique relationship with the park as she was born and grew up in Khao Yai. The primary school teacher mentioned:

I was born in Khao Yai. I have studied in other places, but finally I could come back to work at this place. I think my life is bound to here. I really think this national park is important as my home.

Similarly, a village chief also responded that the park was considered as a "home" and "shelter" for the local people. He was satisfied with the employment opportunities generated by tourism for the younger generations nowadays. He appreciated that his children do not need to travel far from their hometown since they could easily get a job in Khao Yai and spend more times with the family. The respondent also believed that it has indirectly made family bonding closer.

\section{Cultural and Traditional Practices in Conserving the Park}

Other reasons that cause positive perspectives on nature conservation among the local communities in Khao Yai could be associated with their community cultural and traditional practices in protecting national parks. The children are always taught by their parents to look after the forests and consider the jungle as their homes. They would not disturb the forest resources which they have regarded as treasures.

The phrase "the kids will notice and continue this culture" illustrates that the villagers still believed that the treasures of forest should be safeguarded continuously and handed down through generations, as same as their traditions. We quoted the opinion of one villager who operated a resort as follows:

We were being educated since young by our parents to conserve the environment, love the animals, do not harm the animals, and do not waste the resources... We will continue this culture by applying the same value to educate our kids.

She further substantiated evidence that most of the villagers in Khao Yai endure their lives in a simple way from the very beginning. She defended the ways of their founding fathers in the past were originally finding food on their own was done by hunting and harvesting from the forest. She felt grateful to the ancestors with regard to their ways of using natural resources which are friendly, moral and ethical in consumption, where they would only take sufficient amount for their needs in order to save the forest and its wildlife for their children and grandchildren. The history of traditional practices on conservation by their ancestors has been illustrated in the following quote. 
When I heard from the old people about their ways of harvesting the forest resources, I was so thankful and appreciated their good attitudes... They would not take everything out from the forest, but they would leave some behind to let them reproduce themselves. So, with that way, our next generations will be able enjoy what they had.

\section{Rituals and Beliefs about the Forest I: The Sacred Godfather of Khao Yai}

When the respondents were asked to share their local beliefs about the forest such as sacred things and taboos in the forest, all of them mentioned that the Khao Yai Godfather is believed to occupy the forest. He is originally from Khao Yai and exists since the old generation. The local people strongly believed that He protects the local populations. Therefore, He has been dubbed as the Godfather of Khao Yai. He is the God of the forest or the King who owns and rules the lands with specific responsibility for the spiritual maintenance of the sacred nature. $\mathrm{He}$ is the only one who has the highest power and respect from the surrounding communities. A farmer of a corn plantation explained the story as follows:

Godfather of Khao Yai is the one who holds the most power in the forest. He is the leader or King that rules this mountain... I believe He is the one who chases away bad people. Anyone who goes up to the mountain needs to pray to the Almighty Father, as they would be praying for protection, luck, and prosperity as well.

Another distinct interview with a female resident who was a retired civil servant, disclosed that she believed there are thousands of creatures that could harm or kill the people deep in the forest. Anyhow, she has a strong confidence that the sacred God could help the people from being lost in the forest and avoid the dangers of wild animals. In order to escape from the dangers of the jungle, all the local people and visitors have to pray for the protection from the Khao Yai Godfather before entering the forest. She told an incredible story of survival of a tourist who had lost in the national park for a couple of days.
Somebody has led him out to safety, she said.

The sacred God of Khao Yai would also help one who get lost in the jungle... I heard a true story about a tourist who got lost in the national park for three to four days. He tried to find a way out, but he kept going towards the same direction and couldn't find the exit. Finally, somebody came to guide him and disappeared without a trace.

The observational data during the site visit showed the shrine of the Almighty Godfather has been built at the entrance of the Khao Yai National Park. It is convenient for the people who wish to pray for the protection from the Godfather. Everybody would stop for pray before entering the park, to ask for permission into the forest and the blessing for a safe trip. Besides praying for safety in the forest, they would also pray for luck and wealth from the Almighty God. The local villagers mentioned that they would conduct the ceremony to the sacred one by winter season every year during the end of January. They would bring offerings of chicken and boar's head to pray to the Godfather to end all types of bad luck.

Walking closer to the Godfather shrine, we could also observe the sacrifices may not involve the killing of an animal, whereby the statues of wild animals were often used as less bloody offerings to the Gods. Praying and sacrificial offerings using elephants and fighting cocks have truly presented the culture and tradition of Thailand. The shrine was surrounded by plenty of the animal statues which were referred as the followers of the Almighty God as the military and weapons belonging to the sacred one.

\section{Rituals and Beliefs about the Forest II: The Myth of the Ta-kien Godmother}

There were also other popular legends amongst the local communities that are associated with the Godmother of Ta-kien and her sister which have been mentioned during the interviews. When telling the story of the sacred Godmother, a respondent said that the word Ta-kien means the "big wood" in Thai language. The myth of the Godmother came from a Ta-kien wood 
buried underneath the soil of a river near to Moo 6. It was happened not more than two years ago, when a worker of a resort often had a dream about the Ta-kien Mother. She got into his dream to ask for help to pull her body up from the river. An elder who was previously a village chief told the story:

The Godmother of Ta-kien sneaked into the dreams of a resort worker in Khao Yai and said that she was staying inside a Ta-kien wood under a river. She was cold and wanted to go out from there.

Afterwards, few tractors were used to dig up a big wood from the river and the Godmother of Ta-kien appeared herself by letting few people see her face on the wood. She also came out from the wood just to notify the people that she was there, a respondent informed. The big Ta-kien wood was then moved by a truck and dwelled at the temple of Moo 6. Few months later, the Godmother crept into the dream of a villager and told said that her sister was still under the river. Soon after that, a smaller Ta-kien wood was also dug out from the same location and placed in the temple. Many local people as well as people from other provinces in Thailand came to pray for the Ta-kien Godmother and her sister to wish for goodwill and things to come around successfully. The field observation also recorded the temple was full of the payoffs from the prayers including the servants, beautiful dresses, makeup desk and jewellery.

Both Ta-kien Godmother and her sister are not alone, because they are accompanied by their servants and all those beautiful stuffs. All these are the pay-off from those who had succeeded. Almost hundred dresses there and some of them might cost more than thousands.

\section{Discussion}

As a whole, this study confirms that the community cultures and traditions are the prime contributors to supportive attitudes towards nature conservation efforts surrounding the Khao Yai National Park in Thailand. The main reason of having a positive attitude is that the forest is not just important for wildlife conservation, but also shapes their custom, cultures, traditions and beliefs about the spirits of the nature.

The argument of Brown and Verschuuren (2018) that cultural and spiritual bonds with "nature" are among the strongest motivators for nature conservation has been proven in this study. The authors argue that the protected area managers should acknowledge the rights, responsibilities, obligations, and aspirations of stakeholder groups and to recognise the cultural and spiritual significance that "nature" holds for people. In this study, the Khao Yai National Park inspires a sense of belonging among the local villagers where they viewed the park as a home, a place where they were born, and a place where they grew up. In order to protect their land of birth, they have presented strong support for forest and wildlife conservation activities.

Moreover, the existence of the national park has been argued to improve the personal relationship between villagers over the decades (Brunt \& Courtney, 1999; Teh \& Nik Norma, 2015; Zhuang et al., 2019). Based on the interview responses, a village chief suggested that the employment opportunities generated for the young generations are associated with the development projects surrounding Khao Yai. He admitted that this has improved the family's intimacy by saying that "our children could easily get a job in Khao Yai and could spend more time with the family".

Interviews with the respondents also discovered the tradition of conserving the park was embraced by the local people which has been inherited from generation to generation is still maintained. They perceived the environmental resources that enrich their present living should be safeguarded and monitored continuously to enrich the life of their children and grandchildren in the future. They have started being responsibile in protecting biodiversity since decades ago, and this culture has been well-preserved from the elders to their descendants.

Negi (2005) reported that religious belief and rituals are very much inter-linked and 
intimately related to management of the natural biodiversity. In Thailand, about 94 per cent of the population is Buddhist and this figure provides great implications on the environmental attitudes of Thai people. According to the Buddha's teaching, all lives including the plants should not be destroyed, so that humanity may enjoy its presence (Kariyawasam, 2007). Forest and trees are sacred and preserved as they are considered as the source of human life, therefore they must be maintained and should not be disturbed. Buddhism in Thailand has been the guiding force for more than a thousand years, in all aspects, of how Thai's lead their lives (Kusalasaya, 2005), and hence have influenced their attitudes towards others, including their relationship with all creatures and plant life (Negi, 2005).

In many countries, traditional cultural practices in the light of religious beliefs, rituals and taboos are seen as the driving force and highly effective in the conservation of biodiversity (Adom, 2016; Taena et al., 2016; Murray \& Agyare, 2018). In India, for example, trees and forest are believed to be inhabited by spirits and therefore it is forbidden to utilise them. A violation of this may spark anger from the spirits (Begossi, 2012). In some African countries, taboos are used as a guide for upholding of social morality. There exist some customary rules that prevent people from cutting trees near waterways (Doroigbo et al., 2011).

In line with these previous studies, the interviewers did with the local communities in Khao Yai and the thorough observations on their daily lifestyles have also unearthed the environmental history of the sacred forest. Taboo plays a role in directing their behaviours in managing natural environment and resources. The respondents held the view that nature must be preserved because it consists of a sacred and supernatural force. They believed that the forests are the most mysterious place that deals with the world of spirits, where everybody should pay their respects. If the forest and trees are destroyed, the spirits will disturb people living around it. Therefore, the local people surrounding Khao Yai National Park have long protected their sacred forests as a way to observe their cultural taboos and beliefs.

In addition, the local villagers also shared their rituals and beliefs about the sacred taboo of forests including the legends of the Almighty Godfather of Khao Yai and the Godmother of Ta-kien. Since ancient times, the forest is believed to be home of spirits. According to the interviewees, the presence of the Almighty God's spirits is required to look after the forests and mountains, even before the foundation of the national park. From the culturally and historically aspects, they have strong beliefs that Godfather plays an important role in protecting the local people, particularly those who get lost in the jungle. The locals and also the visitors always pray for their protection before entering the park, or whenever the incidents occur. This result supports the beliefs about traditional spiritual values of forest which have played a role in protecting the Thai people until now (Byers, Cunliffe \& Hudak, 2001).

\section{Conclusion}

Overall, our results have important implications for nature conservation in Thailand. The study confirms the protection of forest resources as one of their traditional customs, inherited from the older generation. These practices should be followed by the youngsters of the community to ensure the continuity of this cultural tradition could be secured, which has been highlighted by the respondents as "keeping the culture continuously" during the interviews. The study also reveals that the sacred elements in nature do lead people to become committed to environmental causes, particularly when religious identities emphasise conceptualisation of human as caretakers of this planet (Sachdeva, 2016).

Relatively, this study suggests understanding the community cultures and traditions contribute to greater understandings of their attitudes towards park protection. For the long-term sustainability of the national park, 
it is important that local support and goodwill for nature conservation be nurtured (Ntuli et al., 2019; Zhang et al., 2020). Without such support, environmental resources may be threatened. Therefore, it is concluded in this study that the inclusion of local people as well as their cultural practices as major determinants of success or failure for the conservation goals. These research findings would assist policy makers or park managers to develop sustainability conservation strategies, for the benefits of the local communities and national economy at large.

\section{Limitations and Suggestions for Future Research}

The main limitation of this study lies on the potential cultural misunderstandings and language mistranslations. All of the respondents speak Thai as their native language. In order to conduct interviews in a foreign language, this study employed an interpreter who is a native and well-versed with Thai culture that can converse easily with the respondents. Other limitations of this research are related to insufficient financial resources and time to conduct more in-depth data collection. Time constraints imposed by limited financial resources has reduced the data collection period to two weeks.

To overcome the limitations of this study, future research should be conducted over extended periods of time in order to include a larger number of rural areas near to the national park. This would better capture discrepancies of local residents' perspectives on nature conservation. This research only focused on the local communities who are living within Khao Yai National Park in Thailand as its target respondents. More studies need to be conducted in other protected areas of different countries, using this study as a baseline. Hence, the variations of different community cultures and traditions in contributing to influence local perceptions would have been better understood.

\section{Acknowledgements}

This research would not have been possible without the funding provided by MyBrain 15 . The authors wish to thank the respondents at Khao Yai National Park, Thailand for participating in this research.

\section{References}

Abukari, H., \& Mwalyosi, R. B. (2020). Local communities' perceptions about the impact of protected areas on livelihoods and community development. Global Ecology and Conservation, 22, 1-12.

Adams, W. M., \& Hutton, J. (2007). People, parks and poverty: Political ecology and biodiversity conservation. Conservation and Society, 5(2), 147-183.

Adler, N. J. (1991). Communicating across cultural barriers. International Dimensions of Organizational Behaviour (Eds.). Boston, MA: PWS-KENT Publishing Company.

Adom, D. (2016). Inclusion of local people and their cultural practices in biodiversity conservation: Lessons from successful nations. American Journal of Environmental Protection, 4(3), 67-78.

Allendorf, T. D., Brandt, J. S., \& Yang, J. M. (2014). Local perceptions of Tibetan village sacred forests in northwest Yunnan. Biological Conservation, 169, 303-310.

Anderson, K., \& Gale, F. (1992). Introduction. In K. Anderson \& F. Gale (Eds.), Inventing places: Studies in cultural geography (pp. 1-14). Melbourne: Longman Cheshire.

Begossi,A.(2012). Resilience and neotraditional population: The caicaras of the Atlantic forest and cabaclos of the amazon (Brazil). 7. Indigenous African Resource Sacred Ecology Netpris, 480-Sacred Ecology-2012- (9780415517324).

Bennett, N. J., \& Dearden, P. (2014). Why local people do not support conservation: Community perceptions of marine protected area livelihood impacts, governance and 
management in Thailand. Marine Policy, 44, 107-116.

Berbés-Blázquez, M., Bunch, M. J., Mulvihill, P. R., Peterson, G. D., \& van Wendel de Joode, B. (2017). Understanding how access shapes the transformation of ecosystem services to human well-being with an example from Costa Rica. Ecosystem Services, 28, 320327.

Blau, P. M. (1964). Exchange and power in social life. New York: Wiley.

Bragagnolo, C., Malhado, A. M., Jepson, P., \& Ladle, R. (2016) Modelling local attitudes to protected areas in developing countries. Conservation and Society, 14(3), 163-182.

Brown, S., \& Verschuuren, B. (2018). Cultural and spiritual significance of nature in protected and conserved areas: The 'deeply seated bond'. In B. Verschuuren \& S. Brown (Eds.), Cultural and Spiritual Significance of Nature in Protected Areas: Governance, Management and Policy (1 $1^{\text {st }}$ ed., pp. 1-17). London, UK: Routledge.

Brunt, P., \& Courtney, P. (1999). Host perceptions of sociocultural impacts. Annals of Tourism Research, 26 (3), 493-515.

Byers, B. A., Cunliffe, R. N., \& Hudak, A. T. (2001). Linking the conservation of culture and nature: A case study of sacred forests in Zimbabwe. USDA Forest Service / UNL Faculty Publications, Paper 191.

Byers, B. A., Cunliffe, R. N., \& Hudak, A. T. (2001). Linking the conservation of culture and nature: A case study of sacred forests in Zimbabwe. USDA Forest Service / UNL Faculty Publications, Paper 191.

Cadena, A. J. (2014). (Un)protected Areas: Rosewood poaching in Thailand's Dong Phayayen-Khao Yai World Heritage Site. https://www.iucn.org/content/unprotectedareas-rosewood-poaching-thailands-dongphayayen-khao-yai-world-heritage-site

Chibucos, T. R., Leite, R. W., \& Weis, D. L. (2005). Readings in family theory. Thousand Oaks: Sage.
Clements, G. R., Lynam, A. J., Gaveau, D., Yap, W. L., Lhota, S., Goosem, M., \& Laurance, W. F. (2014). Where and how are roads endangering mammals in Southeast Asia's forests? PLoS ONE, 9(12), e115376.

Doroigbo, C. I., Ibeawuchi, II., Aja, O. O., \& Ejiogu-Okereke, E. N. (2011). Indigenous technologies for adaptation and mitigation of climate change in Sub-Sahara Africa. International Journal of Agriculture and Rural Development, 14(2), 630-637.

Driscoll, D. L. (2011). Introduction to primary research: Observations, surveys, and interviews. Library of Congress Catalogingin-Publication Data.

Garekae, H., Thakadu, O. T., \& Lepetu, J. (2016). Attitudes of local communities towards forest conservation in Botswana: A case study of Chobe Forest Reserve. International Forestry Review, 18(2), 180191.

Guzman, A., Heinen, J. T., \& Sah, J. P. (2020). Evaluating the conservation attitudes, awareness and knowledge of residents towards Vieques National Wildlife Refuge, Puerto Rico. Conservation and Society, 18(1), 13-24.

Harun, R., Chiciudean, G. O., Sirwan, K., Arion, F. H., \& Muresan, I. C. (2018). Attitudes and perceptions of the local community towards sustainable tourism development in Kurdistan Regional Government, Iraq. Sustainability, 10, 2991.

Head, L., Trigger, D., \& Mulcock, J. (2005). Culture as concept and influence in environmental research and management. Conservation and Society, 3(2), 251-264.

Heath, B. L. (2013). Encyclopedia of public relations. Los Angeles: SAGE Publications.

Homans, G. C. (1961). Social behaviour: Its elementary forms. New York: Harcourt Brace Jovanavich.

Hope, A. L. B., \& Jones, C. R. (2014). The impact of religious faith on attitudes to environmental issues and carbon capture 
and storage (CCS) technologies. Technology in Society, 38, 48-59.

Jaafar, M., Kayat, K., Tangit, T. M., \& Yacob, M. F. (2013). Nature-based rural tourism and its economic benefits: A case study of Kinabalu National Park. Worldwide Hospitality and Tourism Themes, 5(4), 342352.

Jeanrenaud, S. (2002). People-oriented approaches in global conservation: Is the leopard changing its spots? London: International Institute for Environment and Development, and Institute for Development Studies.

Jenks, K. E., Songsasen, N., Kanchanasaka, B., Bhumpakphan, N., Wanghongsa, S., \& Leimgruber, P. (2013). Nat. Hist. Bull. Siam. Soc., 59(2), 65-76.

Kabra, A. (2009). Consrvationinduced displacement: A comparative study of two indian protected areas. Conservation and Society, 7(4), 249-267.

Kariyawasam, A. G. S. (2007). http://www. maithri.com/articles_new/Buddha's_ affinity_for_the_environment.htm

Krauss, R. M., \& Fussell, S. R. (1996). Social psychological models of interpersonal communication. In E. T. Higgins, \& A. Kruglanski (Eds.), Social psychology: A handbook of basic principles (pp. 655-701). New York: Guilford.

Krauss, R. M., \& Morsella, E. (2000). Communication and conflict. In Deutsch, M., \& Coleman, P. (Eds.), The handbook of constructive conflict resolution: Theory and practice (pp. 131-143). San Francisco: Jossey-Bass.

Kusalasaya, K. (2005). Buddhism in Thailand: Its past and its present. Buddhist Publication Society: Wheel Publication.

Labov, W. (1982). Speech actions and reactions in personal narrative. In D. Tannen (Ed.), Analyzing discourse: Text and talk. Washington, DC: Georgetown University Press.
Laungaramsri, P. (2001). Redefining nature: Karen ecological knowledge and the challenge to the modern conservation paradigm. Chiang Mai: Earthworm Books.

Mamo, Y. (2015). Attitudes and perceptions of the local people towards benefits and conflicts they get from conservation of the Bale Mountains National Park and Mountain Nyala (Tragelaphus buxtoni), Ethiopia. International Journal of Biodiversity and Conservation, 7(1), 28-40.

Massé, F. (2016). The political ecology of human-wildlife conflict: Producing wilderness, insecurity, and displacement in the Limpopo National Park. Conservation and Society, 14(2), 100-111.

McKay, R., \& Whitehouse, H. (2015). Religion and morality. Psychological Bulletin, 141(2), 447-473.

Muhumuza, M., \& Balkwill, K. (2013). Factors affecting the success of conserving biodiversity in national parks: A review of case studies from Africa. https://www. hindawi.com/journals/ijbd/2013/798101/

Munanura, I. E., Backman, K. F., Hallo, J. C., Powell, R. B., \& Sabuhoro, E. (2018). Understanding the relationship between livelihood constraints of poor forestadjacent residents, and illegal forest use, at Volcanoes National Park, Rwanda. Conservation and Society, 16(3), 291-304.

Murray, G., \& Agyare, A. (2018). Religion and perceptions of community-based conservation in Ghana, West Africa. PLoS ONE, 13(4), e0195498.

Mutanga, C. N., Muboko, N., \& Gandiwa, E. (2017). Protected area staff and local community viewpoints: A qualitative assessment of conservation relationships in Zimbabwe. PLoS ONE, 12(5), e0177153.

Myers, M. D. (2013). Qualitative research in business and management. (Eds.). London, UK: Sage Publications. 
Myers, S. (2016). Wildlife of Southeast Asia. Princeton and Oxford: Princeton University Press.

Nana, E. D., \& Tchamadeu, N. N. (2014). Socioeconomic impacts of protected areas on people living close to the Mount Cameroon National Park. Parks Journal, 20(2), 129137.

Negi, C. S. (2005). Religion and biodiversity conservation: Not a mere analogy. International Journal of Biodiversity Science and Management, 1(2), 85-96.

Ntuli, H., Jagers, S. C., Linell, A., Sjostedt, M., \& Muchapondwa, E. (2019). Factors influencing local communities' perceptions towards conservation of transboundary wildlife resources: The case of the Great Limpopo Trans-frontier Conservation Area. Biodiversity and Conservation, 28, 29773003.

Panusittikorn, P., \& Prato, T. (2001). Conservation of protected areas in Thailand: The case of Khao Yai National Park. The George Wright Forum, 18, 66-76.

Park, C. L. (2005). Religion and meaning. In Paloutzian, R. F., \& Park, C. L. (Eds.), Handbook of the psychology of religion and spirituality (pp. 295-314). New York, NY: Guilford Press.

Pham, H. L. (2012). Tourism impacts and support for tourism development in Ha Long Bay, Vietnam: An examination of residents' perceptions. Asian Social Science, 8(8), 2839.

Richmond, H. J. (2002). Learners' lives: A narrative analysis. The qualitative report, 7(3), 1-14.

Sachdeva, S. (2016). Religious identity, beliefs, and views about climate change. Oxford Research Encyclopedia of Climate Science. http://dx.doi.org/10.1093/acrefore/ 9780190228620.013.335

Sampieri, H., Collado, C. F., \& Lucio, P. B. (2006). Methodologia de Pesquira. Lisboa: McGraw-Hill.
Shahabuddin, G., \& Bhamidipati, P. L. (2014). Conservation-induced displacement: Recent perspectives from India. Environmental Justice, 7(5), 122-129.

Suwanwaree, P., \& Aroon, S. (2014). Vertebrates killed on the main road in Khao Yai National Park, Thailand. http://www.researchgate. net/publication/270280550

Taena, L., Sailan, Z., Nalefo, L., Basri, A., Laepe, A., Samsul, Helmina, S., Miliha, L., \& Kuasa, W. (2016). The cultural tradition of "Falia" in preserving forest by Munanese ethnic. Journal of Sustainable Development, 9(5), 200-206.

Teh, K. Y., \& Nik Norma, N. H. (2015). Local communities' perspectives towards nature conservation: A study of Taman Negara Pahang, Kuala Tahan Malaysia. Health and the Environment Journal, 6(1), 1-10.

Thaworn, R., Kelley, L., \& Yasmi, Y. (2010). Can biodiversity conservation go hand in hand with local livelihoods? A case of conflict resolution in Thailand. Unasylva, 236(61), 28-33.

Thondhlana, G., \& Cundill, G. (2017). Local people and conservation officials' perceptions on relationships and conflicts in South African protected areas. International Journal of Biodiversity Science, Ecosystem Services \& Management, 13(1), 204-215.

Timsina, T. P. (2014). Conflict of local people and larger mammals - A case of Chitwan National Park in Central Nepal. Journal of Advanced Academic Research, 1(1), 99106.

Triguero-Mas, M., Olomi-Sola, M., Jha, N., Zorondo-Rodrigues, F., \& Reyes-Garcia, V. (2010). Urban and rural perceptions of protected areas: A case study in Dandeli Wildlife Sanctuary, Western Ghats, India. Environmental Conservation, 36, 208-217.

UNESCO. (2013). Convention concerning the protection of the world cultural and natural heritage. http://whc.unesco.org/ document/135267 
Vimal, R., Khalil-Lortie, M., \& Gatiso, T. (2018). What does community participation in nature protection mean? The case of tropical national parks in Africa. Foundation for Environmental Conservation, 1-9.

Watson, J. E. M., Dudley, N., Segan, D. B., \& Hockings, M. (2014). The performance and potential of protected areas. Nature, 515, 67-73.

Zhang, Y., Xiao, X., Cao, R., Zheng, C., Guo, Y., \& Gong, W. (2020). How important is community particiaptiob to ecoenvironemntal conservation in protected areas? From the perspective of predicting locals' pro-environmental behaviours. Science of the Total Environment, 739.

Zhuang, X., Yao, Y., \& Li, J. (2019). Socialcultural impacts of tourism on residents of World Cultural Heritage Sites in China. Sustainability, 11, 840. 